$10-6-2020$

\title{
Salinity and Simulated Herbivory Influence Spartina alterniflora Traits and Defense Strategy
}

Serina Sebilian Wittyngham

Virginia Institute of Marine Science

Follow this and additional works at: https://scholarworks.wm.edu/vimsarticles

Part of the Marine Biology Commons

\section{Recommended Citation}

Wittyngham, Serina Sebilian, Salinity and Simulated Herbivory Influence Spartina alterniflora Traits and Defense Strategy (2020). Estuaries and Coasts. doi: $10.1007 / \mathrm{s} 12237-020-00841-x$

This Article is brought to you for free and open access by the Virginia Institute of Marine Science at W\&M ScholarWorks. It has been accepted for inclusion in VIMS Articles by an authorized administrator of W\&M ScholarWorks. For more information, please contact scholarworks@wm.edu. 
Salinity and simulated herbivory influence Spartina alterniflora traits and defense strategy

\author{
Serina S. Wittyngham*1
}

$3 \quad{ }^{1}$ Virginia Institute of Marine Science, William \& Mary, 1370 Greate Road, Gloucester Point, VA

$4 \quad 23062$

$5 \quad$ *corresponding author: sswittyngham@vims.edu; (804) 684-7383

6 Abstract

7 Sea-level rise is expected to push saline waters into previously fresher regions of estuaries, and

8 higher salinities may expose oligohaline marshes to invertebrate herbivores typically constrained

9 by salinity. The smooth cordgrass, Spartina alterniflora (syn. Sporobolus alterniflorus), can

10 defend itself against herbivores in polyhaline marshes, however it is not known if $S$.

11 alterniflora's defense varies along the mesohaline to oligohaline marsh gradient in estuaries. I

12 found that S. alterniflora from a mesohaline marsh is better defended than plants from an

13 oligohaline marsh, supporting the optimal-defense theory. Higher salinity treatments lowered

14 carbon content, $\mathrm{C}: \mathrm{N}$, and new stem biomass production, traits associated with a tolerance

15 strategy, suggesting that salinity may mediate the defense response of S. alterniflora. Further,

16 simulated herbivory increased the nitrogen content and decreased C:N of S. alterniflora. This

17 indicates that grazing may increase S. alterniflora susceptibility to future herbivory via improved

18 forage quality. Simulated herbivory also decreased both belowground and new stem biomass

19 production, highlighting a potential pathway in which herbivory can indirectly facilitate marsh

20 loss, as S. alterniflora biomass is critical for vertical accretion and marsh stability under future

21 sea-level rise scenarios.

22 Keywords: tolerance, resistance, plant-defense strategy, functional traits, salt marsh 


\section{Introduction}

Tidal marshes are responsible for ecosystem services that contribute to human well-being

26

27

including carbon sequestration, erosion control, and nutrient cycling (DeGroot et al. 2012;

Costanza et al. 2014). Tidal marshes occur along natural salinity gradients within estuaries and are typically categorized by their salinity regime (e.g. oligohaline -0 to 5 ppt, mesohaline -5 to 18 ppt, and polyhaline - 18 to 30 ppt) (Odum 1988; Montagna et al. 2013). In the Chesapeake Bay region, accelerated sea-level rise is a threat to tidal marshes (Najjar et al. 2010). Average sea-level rise in this region is $\sim 3.80 \mathrm{~mm} \mathrm{yr}^{-1}$, which is 3-4 times higher than the global mean of 0.98 $\mathrm{mm} \mathrm{yr}^{-1}$ (Sallenger et al. 2012; Boon \& Mitchell 2015). A marsh’s ability to keep pace with sea-level rise depends on sediment size and supply (Kirwan et al. 2010), and vegetation stem density and biomass production, both above- and belowground (Leonard \& Luther 1995; Elsey-Quirk \& Unger 2018). Marsh vegetation is responsible for regulating the process of vertical accretion, as plant stems trap sediments above ground and accumulate organic matter below ground (Kirwan \& Megonigal 2013), thus building marsh elevation and keeping pace with rising seas.

In addition to sea-level rise, tidal marshes are threatened by intense herbivory (Gedan et al. 2009; He \& Silliman 2016; Angelini et al. 2018). Many of the invertebrate herbivores implicated in runaway consumption (e.g. the marsh periwinkle, Littoraria irrorata: Silliman et al. 2005; the purple marsh crab, Sesarma reticulatum: Holdredge et al. 2009) are physiologically limited to mesohaline and polyhaline marshes (Staton \& Felder 1992; Henry et al. 1993) and are not found in oligohaline marshes. As sea-level rise pushes saline waters into oligohaline marshes, invertebrate herbivores may follow, increasing the vulnerability of these marshes to herbivory. In some instances, runaway herbivory can remove vegetation from large spatial areas 
47 and transition the marsh to a mudflat (Holdredge et al. 2009; Vu et al. 2017), intensifying marsh

48 susceptibility to drowning; however, despite extreme herbivory, marshes persist. This may be

49 due in part to how plants respond to herbivory pressure. Thus, understanding how marsh plant

50 traits change in response to herbivory provides direct insight into one aspect of marsh resilience.

$51 \quad$ The palatability of plant tissue can control the rate of herbivory (Siska et al. 2002;

52 Salgado \& Pennings 2005), and thus susceptibility to grazing. Following herbivory, many plants

53 can induce changes to their chemical, structural, and morphological traits to mitigate damage and

54 deter further grazing (Ito \& Sakai 2009; Burghardt \& Schmitz 2015), which in combination with

55 constitutive traits, can decrease herbivore consumption and vegetation removal. Alterations in

56 both constitutive and induced traits define the two primary plant defense strategies: tolerance and

57 resistance. Plants can tolerate herbivory by increasing above and belowground biomass

58 production to compensate for mass lost to herbivores (Mauricio et al. 1997; Burghardt \&

59 Schmitz 2015). Alternatively, plants can resist herbivore attack by producing chemical and/or

60 structural defenses to decrease palatability and deter future grazing (Mauricio et al. 1997;

61 Burghardt \& Schmitz 2015). Depending on factors such as environmental conditions or

62 herbivore abundance, these strategies may or may not be mutually exclusive (Mauricio et al.

63 1997; Więski \& Pennings 2014).

64 My overarching goal was to compare plant defense response to simulated herbivory

65 between plants from a mesohaline and oligohaline marsh and to test the hypothesis that salinity

66 can influence plant defense responses. In North Atlantic estuaries, salinity and elevation are key

67 determinants of the vegetative community. The 'low marsh' (below mean high water) of

68 oligohaline marshes typically has high plant diversity, whereas the low marsh of polyhaline

69 marshes is dominated by monotypic stands of the smooth cordgrass, Spartina alterniflora (syn. 
Sporobolus alterniflorus) (Perry \& Atkinson 1997). In the Chesapeake Bay region, S.

71 alterniflora grows along the natural salinity gradient of estuaries and is found in both oligohaline 72 and mesohaline marshes. Thus, it was selected as the focal species of this study. Previous work 73 on S. alterniflora defense response has been focused in polyhaline marshes alone (Pennings et al. 74 1998; Hendricks et al. 2011; Long et al. 2011; Sieg et al. 2013; Long \& Porturas 2014; Więski \& 75 Pennings 2014). It is unclear, however, whether a pattern in S. alterniflora defense exists along 76 the mesohaline to oligohaline marsh gradient, and if so, how this response may be influenced by 77 increasing salinities anticipated with sea-level rise. determine the extent of a plants’ defense response (Herms \& Mattson 1992; Ito \& Sakai 2009).

80 In wetlands, the type of herbivory varies along the natural estuarine salinity gradient. Both 81 oligohaline and mesohaline marshes suffer from vertebrate (e.g. avian and/or mammalian) and 82 insect herbivory (Crain 2008). In addition to vertebrate and insect herbivores, mesohaline 83 marshes also have high abundances of other invertebrate herbivores (e.g. crustaceans and/or 84 mollusks), which are not typically found in oligohaline marshes (Crain 2008; Sutter et al. 2019). 85 Although not explicitly tested in marshes, the type of herbivore inflicting damage may influence plant defense strategy. For example, terrestrial grasses follow a tolerance strategy in response to

87 mammalian herbivores (Frank \& McNaughton 1993) and marine macroalgae follow a resistance strategy in response to invertebrate grazing (Cronin \& Hay 1996). If this pattern holds true for

89 tidal marshes, I would expect S. alterniflora from the oligohaline marsh, where vertebrate 90 herbivory is prevalent, to follow a tolerance strategy. In contrast, I would expect S. alterniflora

91 from the mesohaline marsh, which suffers more from invertebrate herbivory, to more closely 92 align with a resistance strategy. Additionally, although the exact age of these marshes is 
93 unknown, the underlying strata indicate that the mesohaline marsh may be much older than the

94 oligohaline marsh (Hobbs 2009), thus, length of exposure to herbivory may also influence plant

95 defense. Therefore, I expected plant defense response to be greater in the mesohaline marsh

96 which has a longer history of herbivory and a wider variety of herbivores than the oligohaline

97 marsh.

Salinity may also mediate plant defense response, as increased salinity can restrict growth and germination in Spartina spp. (Alberti et al. 2010; Daleo et al. 2015; Infante-Izquierdo et al. 2019), as well as inhibit compensatory growth in response to herbivory (Long \& Porturas 2014).

101 This is particularly important for plants following a tolerance strategy in which compensatory 102 growth is the primary mechanism of defense. Further, salinity directly affects plant tissue 103 stoichiometry (MacTavish \& Cohen 2017; Sutter et al. 2019). Therefore, I expected that $S$. 104 alterniflora in high salinity treatments, regardless of collection site, would have lower carbon 105 content due to decreased photosynthesis and carbon assimilation (MacTavish \& Cohen 2017; 106 Sutter et al. 2019) and higher nitrogen content caused by increased osmolyte production (Munns 107 2002; Sutter et al. 2019), both of which contribute to lower C:N.

A trait-based approach was used to quantify the defense response of S. alterniflora. For example, if S. alterniflora were to follow a resistance strategy, I expected to see increased tissue phenolic concentrations and decreased protein content. Phenolics can lower plant palatability and 111 serve as deterrence against herbivore grazing (Dorenbosch \& Bakker 2011; Zhang et al. 2019), 112 as well as play a role in primary metabolism or UV protection (Close \& McArthur 2002; Neilson 113 et al. 2013). Herbivores forage for proteins to meet metabolic demands (Cebrian et al. 2009), so 114 plants may decrease the concentration of proteins to deter further herbivory. In contrast, if $S$. 115 alterniflora were following a tolerance strategy, I expected to see higher biomass (new stem 
116 and/or belowground) and carbon content, with lower C:N. Elevated biomass production indicates

117 compensatory growth (Long \& Porturas 2014), with both carbon content and C:N influenced by

118 biomass.

119

120 Materials and Methods

121 Collection Sites

122 Spartina alterniflora was collected from two marshes within the York River Estuary

123 (Virginia, USA; Figure 1a), a tributary of the Chesapeake Bay. There are two herbivores of

124 concern in the York River: the marsh periwinkle, Littoraria irrorata, and the purple marsh crab,

125 Sesarma reticulatum. These herbivores have been implicated in the large-scale die-off of U.S.

126 Atlantic polyhaline marshes (Silliman et al. 2005; Bertness et al. 2014). Their distribution in the

127 York River is currently limited to mesohaline and polyhaline marshes, although they are

128 expected to move into oligohaline marshes as sea-level rise pushes saline waters up-estuary.

129 Sweet Hall marsh (37.566087, -76.882472, hereafter 'oligohaline marsh') is near the head of the

130 York River (Figure 1b, circle), has average salinities of 0-3 ppt (VECOS database) and does not

131 have a population of either herbivore (Wittyngham, personal observation). In contrast, Taskinas

132 Creek marsh (37.416330, -76.715054, hereafter 'mesohaline marsh') is located mid-estuary in

133 the York River (Fig. 1b, triangle), has average salinities of 6-14 ppt (VECOS database) and has

134 known populations of both $L$. irrorata (average density of $\sim 44$ snails per $\mathrm{m}^{2}$; Failon et al. 2020)

135 and S. reticulatum (unknown density; Wittyngham, personal observation). Although there are

136 physical differences between the two marshes (e.g., sediment composition and hydrology), the

137 goal of this study was not to make inferences about the marshes themselves, but rather to draw 
138 comparisons between S. alterniflora that have experienced different levels of salinity and 139 herbivory.

\section{Mesocosm Set-up \& Maintenance}

In the summer of 2017, roots and shoots of S. alterniflora were collected from each

142 marsh. All plants were collected within one meter of the marsh edge using a trowel. Individual

143 collected shoots were at least 0.5 meters apart to minimize collecting ramets from the same

144 clone. Roots and rhizomes were kept intact to minimize the impact of collection and transport to

145 the Virginia Institute of Marine Science (VIMS). Two of the S. alterniflora stems from each

146 marsh were planted in an 11-liter nursery pot containing a 90:10 potting mix to sand mixture.

147 Each pot was suspended in a 19-liter bucket. Following planting, each stem was tagged with a

148 unique colored zip tie and one of five salinity treatments $(0,6,14,19$, or $26 \mathrm{ppt})$ was randomly

149 assigned to each replicate bucket, with 5 replicates per treatment. Salinity treatments of 0, 6, and

$15014 \mathrm{ppt}$ are based on average salinities at the oligohaline and mesohaline collection sites (VECOS

151 database), and treatments of 19 and 26 ppt were used to capture salinities expected with future

152 sea-level rise. Each mesocosm was mechanically tidal following the methods of MacTavish \&

153 Cohen (2014), and programmed tidal cycles followed the natural semidiurnal tides of the

154 Chesapeake Bay region. Water was collected directly from the York River (salinity 17-20 ppt)

155 via a flow-through seawater system and salinity was augmented to high treatment levels (19 and

$15626 \mathrm{ppt})$ through the addition of Instant Ocean salts or to low treatment levels (0, 6, and $14 \mathrm{ppt})$ by

157 adding tap water from a garden hose. Reservoir bucket salinity was measured using a handheld

158 YSI ProDSS multiparameter water quality meter and was changed once every three days to avoid

159 algal growth and to maintain nutrient and dissolved oxygen levels. After approximately three

160 weeks of acclimation, one of two S. alterniflora stems from each marsh within each mesocosm 
161 was randomly assigned a clipped treatment to simulate herbivory. Moving from the base of the

162 stem upward, every other leaf was clipped at the ligule with garden shears. This pattern of

163 mechanical herbivory maximized the possibility of eliciting a response within S. alterniflora

164 tissues, while leaving enough remaining aboveground biomass for trait analyses. Clipping was

165 repeated every two weeks to mimic chronic herbivory while still allowing for plant growth.

166 After two months of simulated herbivory and three months of salinity treatments, the

167 experiment ended. At this point aboveground biomass of the original planted shoot was separated

168 from belowground biomass and new clonal stems (produced by asexual rhizomatous growth) at

169 the sediment surface. All belowground biomass and new stems were washed in an outdoor sieve

170 (1 mm² mesh) to remove sediments. New stems were then sorted by stem of origin and separated

171 from belowground biomass. All aboveground biomass was placed in plastic, resealable bags and

172 held in a $-80^{\circ} \mathrm{C}$ freezer to await further processing. All belowground biomass was placed into

173 pre-weighed foil packets and dried in a drying oven at $60^{\circ} \mathrm{C}$ for twelve days, and dry masses

174 were recorded.

175

$176 \quad$ Plant-Trait Analysis

177 Aboveground biomass was lyophilized and ground to a fine powder using a mini Wiley

178 Mill fitted with a 40-mesh sieve. Samples were run on a FlashEA CHN elemental analyzer for

179 carbon and nitrogen analysis and values were calculated using an Acetanilide standard curve.

180 Total soluble protein content was measured using a modified Bradford assay (Wittyngham et al.

181 2019) in which $1 \mathrm{~mL}$ of $1 \mathrm{M} \mathrm{NaOH}$ was added to $5 \mathrm{mg}$ of pulverized plant matter and incubated at

$1824^{\circ} \mathrm{C}$ for 24 hours for extraction. Following incubation, samples were centrifuged at 60G for 15

183 minutes and $30 \mu \mathrm{L}$ of the supernatant was placed in sterile centrifuge tubes. $1.5 \mathrm{~mL}$ of 
184 Coomassie reagent was added to each sample and allowed to incubate at room temperature for

18520 minutes. Absorbance was read at $595 \mathrm{~nm}$ and compared to a bovine serum albumin (BSA)

186 standard curve. All samples and standards were run in duplicate. Total phenolic concentrations

187 were measured using a modified Folin-Ciocalteu protocol (Wittyngham et al. 2019). Three

188 successive extractions (70\%, 70\%, 100\% MeOH) were conducted on 100mg of pulverized plant

189 matter. All three extracts were combined and a $150 \mu \mathrm{L}$ aliquot was added to a sterile centrifuge

190 tube. $150 \mu \mathrm{L}$ of Folin reagent was added to each tube and mixed for two minutes. $800 \mu \mathrm{L}$ of

$1910.5 \mathrm{M}$ sodium bicarbonate $\left(\mathrm{NaHCO}_{3}\right)$ was added to stop the reaction, and then samples were

192 incubated at room temperature for 20 minutes to allow for color development. Absorbance was

193 measured at $760 \mathrm{~nm}$ and compared to a ferulic acid standard curve.

195 Statistical Analysis

196 Statistical analysis was conducted in R (R Core Team, 2019). All responses were tested

197 for normality and homogeneity of variance, and those which did not meet these assumptions

198 were transformed using Box-Cox transformations or were log transformed. Multiple hypotheses

199 were tested for each response using generalized linear models. All models were evaluated with

200 model selection, and Akaike Information Criterion corrected for small sample size (AICc) and

201 weights were used to assess best fit. Any model with a weight greater than 0.1 was assessed

202 further using the anova function. For all models, salinity was treated as a continuous fixed factor,

203 with simulated herbivory treatment and site as categorical fixed factors. Additional covariates for

204 some models included: initial aboveground biomass, new stem biomass, and nitrogen content.

205 Initial biomass and new stem biomass were added to account for a possible nutrient dilution

206 effect, as seen in other studies (Grant et al. 2014; Luo et al. 2019). Significance was set at an

207 alpha of 0.05. 

response variables. There were no significant interactions between variables, therefore additive 212 models were used for all responses.

214 Fig. 2A) and subsequently higher C:N ( $\mathrm{p}=0.04$; Fig. 3A) than S. alterniflora from the oligohaline 215 marsh. As salinity increased, carbon content tended to decrease ( $p=0.063$; Fig. 2B), with the 216 highest carbon content at a salinity of 0 ppt, and lower carbon content in treatments of 14, 19, 217 and 26 ppt (Fig. 2B). In contrast, nitrogen content significantly increased as salinity increased 218 ( $\mathrm{p}=0.02$; Fig. 4A), with the highest nitrogen content at $26 \mathrm{ppt}$, and the lowest nitrogen content at 2190 ppt (Fig. 4A). These results for carbon and nitrogen content lead to an overall decline in C:N 220 with increasing salinity ( $p=0.005$; Fig. 3B). Simulated herbivory via clipping tended to elevate 221 tissue nitrogen content ( $p=0.08$; Fig. 4B) and lower $\mathrm{C}: \mathrm{N}(\mathrm{p}=0.002$; Fig. 3C). Contrary to expectations, there were no effects of collection site, salinity, or clipped 223 treatments on protein and phenolic content. The only significant predictor of protein content was 224 nitrogen content, which had a positive, linear effect ( $p=0.005$; Online Resource 1). Additionally, 225 phenolic concentrations had a significantly positive linear relationship with new stem biomass 226 production ( $\mathrm{p}=0.01$; Online Resource 2$)$. Although new stem biomass tended to increase as 227 salinity increased from 6 ppt to 19 ppt ( $p=0.05$; Fig. 5A), there were no significant differences in 228 new stem biomass production between salinity treatments. Interestingly, new stem biomass was 229 significantly lower in clipped treatments when compared to controls ( $\mathrm{p}=1.36 \mathrm{x} 10^{-6}$; Fig. 5B). 230 Spartina alterniflora from the mesohaline marsh produced more belowground biomass 
231 ( $\mathrm{p}=0.0006$; Fig. 6A) than the oligohaline S. alterniflora and clipped treatments produced less

232 belowground biomass than controls ( $\mathrm{p}=0.04$; Fig. 6B).

233 Discussion

234 I expected that simulated herbivory via clipping would elicit either a resistance (e.g., 235 higher phenolic concentrations and lower protein content) or a tolerance (e.g., increased carbon, 236 C:N and biomass production) defense response in S. alterniflora, as seen in previous polyhaline 237 marsh studies (Johnson \& Jessen 2008; Long et al. 2011; Sieg et al. 2013). Contrary to these 238 expectations, I found no signs of a resistance strategy, as clipping had no effect on the phenolic 239 or protein content of S. alterniflora. In addition, clipping did not elicit a tolerance strategy in S. 240 alterniflora, as clipped plants had significantly lower C: $\mathrm{N}$ and biomass (both belowground and 241 new stem) production than controls, and clipping had no effect on carbon content.

242 There is some evidence, however, that clipped treatments may have stimulated a defense 243 response in S. alterniflora not captured by my measured response variables. When resources are 244 limited, there is a trade-off between growth and defense, and therefore a decline in growth may 245 indicate an investment of resources in anti-herbivore compounds (Coley et al. 1985; Basey \& 246 Jenkins 1993). In my study, clipped treatments decreased both belowground and new stem

247 biomass. Although some phenolics can serve as chemical defense against herbivores in $S$.

248 alterniflora (Sieg et al. 2013), other anti-herbivore compounds such as lignin (Buchsbaum et al. 249 1986), fiber (Buchsbaum et al. 1984), and silica (Massey et al. 2007) were not measured in this 250 study and may have been induced by clipping, resulting in lower biomass production. In addition 251 to these variables, direct measures of tissue toughness should also be included in future studies to 252 better understand their role in herbivore deterrence (Pennings et al. 1998). 
Aside from compensatory biomass production, other traits such as resource allocation, 254 plant morphology, phenological changes, and increased photosynthetic capacity can indicate a tolerance defense response (Stowe et al. 2000; Tiffin 2000). In my study, clipped S. alterniflora 256 tissues had significantly higher nitrogen content than controls. I expected this nitrogen pool to be 257 used for protein synthesis, as I found a positive linear relationship between these variables. 258 Despite these expectations, there was no effect of clipping on protein content, therefore the 259 increased nitrogen could have been used for other functions, such as chlorophyll production. 260 This would increase the photosynthetic capacity of clipped plants, an indicator of a tolerance 261 response (Tiffin 2000).

Based on the optimal-defense theory, I anticipated that S. alterniflora collected from a mesohaline marsh would be better defended against herbivory than plants collected from an 264 oligohaline marsh (Optimal-Defense Theory: Rhoads 1979; Herms \& Mattson 1992; Stamp 265 2003), as mesohaline marshes have a higher diversity of herbivores and incidence of attack 266 (Crain 2008; Sutter et al. 2019). Additionally, Hobbs (2009) found that although the surface 267 sediments of both the mesohaline and oligohaline marsh used in my study are from the 268 Quaternary period, the underlying strata of the mesohaline marsh is from the Tertiary period, 269 indicating that this marsh may be older and thus have a longer history of herbivory. Carbon 270 content, C:N, and belowground biomass were higher in S. alterniflora collected from the 271 mesohaline marsh than the oligohaline marsh. Carbon content and C:N are measures of structural 272 complexity and belowground biomass production provides insights into allocation patterns, all of 273 which indicate a tolerance response (Stowe et al. 2000; Tiffin 2000). These results support the 274 optimal-defense theory and my hypothesis that $S$. alterniflora collected from the mesohaline 275 marsh is more defended than plants from the oligohaline marsh. 
These differences in carbon content, C:N, and belowground biomass production between

277 mesohaline and oligohaline marshes may ultimately be driven by salinity. In a similar mesocosm

278 study, there was a significant effect of salinity (0 to $3 \mathrm{ppt}$ ) on S. alterniflora stoichiometry, with

279 the highest C:N, carbon, and nitrogen content in 0 ppt treatments (Sutter et al. 2015). My results

280 follow similar patterns for carbon and C:N, with both variables declining as salinity increases,

281 regardless of collection site. I found an opposing pattern for nitrogen, with elevated salinity

282 leading to higher nitrogen content. This follows my expectations, as increased nitrogen content

283 may be needed to synthesize osmolytes to combat osmotic stress with higher salinities (Munns

284 2002; Sutter et al. 2019). There was no effect of collection site on nitrogen content, however the

285 declines in carbon and C:N are more pronounced for S. alterniflora from the oligohaline marsh,

286 indicating that plants from the mesohaline marsh may be more resilient to the effects of salinity.

287 Lastly, I hypothesized that S. alterniflora in high salinity treatments would follow a

288 resistance strategy rather than a tolerance strategy, as salinity can inhibit compensatory growth in 289 other Spartina spp. (Spartina densiflora: Alberti et al. 2010, Daleo et al. 2015, Infante-Izquierdo 290 et al. 2019; Spartina foliosa: Long \& Porturas 2014; Spartina maritima: Infante-Izquierdo et al. 291 2019). If S. alterniflora were opting for a resistance strategy instead of a tolerance strategy, I 292 expected increased phenolic concentrations accompanied by declines in protein content, carbon 293 content, and C:N. Although there was no effect of salinity on protein content or phenolic 294 concentrations, S. alterniflora in higher salinity treatments had lower carbon content and C:N.

295 This further indicates that perhaps my measured variables did not fully capture a defense 296 response in S. alterniflora and that future studies should include additional functional traits. It's important to note that the use of clipping to simulate herbivory may serve as a caveat 298 to this study, as mimicked herbivory is not always a perfect surrogate for natural herbivory 
299 (Strauss \& Agrawal 1999). Different herbivores graze S. alterniflora in distinctive ways (e.g. 300 phloem-sucking by Prokelesia marginata; radula-scraping \& fungal cultivation by Littoraria 301 irrorata; clipping and shredding by Sesarma reticulatum), so it can also be difficult to determine 302 which herbivore to mimic. Further, the direct removal of aboveground biomass via clipping may 303 have altered the photosynthetic capacity of S. alterniflora, potentially influencing production. In 304 addition, my study focused on S. alterniflora from only one mesohaline marsh and one 305 oligohaline marsh. Similar future studies should examine plants from multiple marshes to 306 examine these concepts further. Lastly, there are potential drawbacks to applying the classic 307 dichotomy of resistance versus tolerance strategies to tidal marshes. Although each of the traits 308 measured in my study have been used repeatedly to quantify these strategies in the literature, my 309 results demonstrate that factors other than herbivory (e.g. collection site and salinity) can elicit 310 changes in plant traits. I suggest that use of this framework can be important to draw 311 comparisons between ecosystems, such as wetlands versus terrestrial grasslands, however results 312 should be interpreted with caution.

Overall, this study provides insight into S. alterniflora's ability to defend itself against 314 herbivore attack and informs our understanding of marsh resilience against sea-level rise.

315 Through the process of vertical accretion, S. alterniflora plays a key role in elevation 316 maintenance and marsh vulnerability to sea-level rise (Morris et al. 2002; Kirwan \& Megonigal 317 2013). Herbivory on S. alterniflora can remove large patches of vegetation, impacting marsh 318 stability and contributing to marsh loss (Gedan et al. 2009; He \& Silliman 2016; Angelini et al. 319 2018). Both herbivory and salinity are drivers of vegetation diversity and stem density within 320 tidal marshes, and thus can influence accretion capacity (Morris et al. 2002; Elsey-Quirk \& 321 Unger 2018). My results indicate that S. alterniflora exposed to herbivory may have higher 
322 forage quality (e.g. increased nitrogen content, decreased C:N), presenting a positive feedback

323 between herbivory and vegetation die-off.

324 In addition, higher salinities expected with sea-level rise may actually increase the

325 probability of future attack from herbivores via improved forage quality (e.g. increased nitrogen

326 content, decreased carbon content and C:N). Spartina alterniflora from the mesohaline marsh

327 had enhanced tolerance traits when compared to its oligohaline counterpart, demonstrating that

328 these marshes may be more resilient to herbivory. As sea level rises and pushes saline waters

329 into fresher regions of estuaries, invertebrate herbivores previously constrained by salinity may

330 establish in oligohaline marshes, potentially increasing their vulnerability to runaway herbivory

331 and thus sea-level rise.

332 Finally, a decline in S. alterniflora biomass production caused by herbivory may

333 ultimately decrease the marsh's ability to vertically accrete and keep pace with sea-level rise, as

334 this process is a function of belowground organic matter accumulation and sediment deposition,

335 which is controlled, in part, by stem density (Elsey-Quirk \& Unger 2018). Although these results

336 present a pathway to marsh loss, many marshes remain intact, despite the presence of herbivores.

337 This study highlights that though widespread marsh loss from herbivory can occur (Silliman et

338 al. 2005; Davidson \& de Rivera 2010; Bertness et al. 2014), this may not be a universal response.

339 Thus, in addition to biotic interactions, ecologists must also consider the geomorphic (e.g.

340 sediment supply) and biogeochemical (e.g. carbon storage in peat) feedbacks that contribute to

341 marsh stability.

342 


\section{Acknowledgments}

I thank the following people for help in the field and laboratory: Bethany Williams, Danielle

Doucette, and Manisha Pant, and special thanks to Caroline Failon for her hard work and dedication to my mesocosms. Thank you to the Chesapeake Bay National Estuarine Research Reserve of Virginia (CBNERR-VA) for access to the collection sites. I am thankful to the Virginia Institute of Marine Science, Virginia Sea Grant (grant \#V721500), and the National Science Foundation (grant \#1832221) for funding this project. Additional gratitude goes to Dr. David Johnson for his support and comments which improved this manuscript. Lastly, I thank Bucket Head and my Tevas for never tiring of algae. This paper is Contribution No. 3949 of the Virginia Institute of Marine Science, William \& Mary.

\section{References}

Alberti, J., A.M. Casariego, P. Daleo, E. Fanjul, B. Silliman, M. Bertness, and O. Iribarne. 2010. Abiotic stress mediates top-down and bottom-up control in a Southwestern Atlantic salt marsh. Oecologia, 163: 181-191.

Angelini, C., S.G. van Montfrans, M.J.S. Hensel, Q. He, and B.R. Silliman. 2018. The importance of an underestimated grazer under climate change: how crab density, consumer competition, and physical stress affect salt marsh resilience. Oecologia, 187: 205-217.

Basey, J.M. and S.H. Jenkins. 1993. Production of chemical defenses in relation to plant growth rate. Oikos, 68: 323-328.

Bertness, M., C.P. Brisson, T.C. Coverdale, M.C. Bevil, S.M. Crotty, and E.R. Suglia. 2014. Experimental predator removal causes rapid salt marsh die-off. Ecology Letters, 17: 830-835.

Boon, J.D. and M. Mitchell. 2015. Nonlinear change in sea level observed at North American tide stations. Journal of Coastal Research. 31: 1295-1305.

Buchsbaum, R., I. Valiela, and T. Swain. 1984. The role of phenolic compounds and other plant constituents in feeding by Canada Geese in a coastal marsh. Oecologia, 63: 343-349.

Buchsbaum, R., J. Wilson, and I. Valiela. 1986. Digestibility of plant constituents by Canada Geese and Atlantic Brant. Ecology, 67: 386-393.

Burghardt, K.T. and O. J. Schmitz. 2015. Influence of plant defenses and nutrients on trophic control of ecosystems. In Trophic Ecology: Bottom-Up and Top-Down Interactions across Aquatic and Terrestrial Systems, eds. T.C. Hanley and K.J. LaPierre, 203-232. Cambridge University Press.

Cebrian, J., J.B. Shurin, E.T. Borer, B.J. Cardinale, J.T. Ngai, M.D. Smith, and W.F. Fagan. 2009. Producer nutritional quality controls ecosystem trophic structure. PLOS ONE. doi: 10.137/journal.pone.0004929. 
Close, D.C. and C. McArthur. 2002. Rethinking the role of many plant phenolics: protection from photodamage not herbivores? Oikos, 99: 166-172.

Coley, P.D., J.P. Bryant, and F.S. Chapin III. 1985. Resource availability and plant antiherbivore defense. Science, 230: 895-905.

Costanza, R., R. de Groot, P. Sutton, S. van der Ploeg, S.J. Anderson, I. Kubiszewski, S. Farber, and R.K. Turner. 2014. Changes in the global value of ecosystem services. Global Environmental Change, 26: 152-158.

Crain, C.M. 2008. Interactions between marsh plant species vary in direction and strength depending on environmental and consumer context. Journal of Ecology, 92: 166-173.

Cronin, G. and Hay, M.E. 1996. Induction of seaweed chemical defenses by amphipod grazing. Ecology, 77: 2287-2301.

Daleo, P., J. Alberti, C.M. Bruschetti, J. Pascual, O. Iribarne, and B.R. Silliman. 2015. Physical stress modifies top-down and bottom-up forcing on plant growth and reproduction in a coastal ecosystem. Ecology, 96: 2147-2156.

Davidson, T.M. and C.E. de Rivera. 2010. Accelerated erosion of saltmarshes infested by the non-native burrowing crustacean Sphaeroma quoianum. Marine Ecology Progress Series, 419: 129-136.

de Groot, R., L. Brander, S. van der Ploeg, R. Costanza, F. Bernard, L. Braat, M. Christie, N. Crossman, A. Ghermandi, L. Hein, S. Hussain, P. Kumar, A. McVittie, R. Portela, L.C. Rodriguez, P. ten Brink, and P. van Beukering. 2012. Global estimates of the value of ecosystems and their services in monetary units. Ecosystem Services, 1: 50-61.

Dorenbosch, M. and E.S. Bakker. 2012. Effects of contrasting omnivorous fish on submerged macrophyte biomass in temperate lakes: a mesocosm experiment. Freshwater Biology, 57: 1360-1372.

Elsey-Quirk, T. and V. Unger. 2018. Geomorphic influences on the contribution of vegetation to soil C accumulation and accretion in Spartina alterniflora marshes. Biogeosciences, 15:379397.

Failon, C.M., S.S. Wittyngham, and D.S. Johnson. 2020. Ecological associations of Littoraria irrorata with Spartina cynosuroides and Spartina alterniflora. Wetlands. doi: 10.1007/s13157-020-01306-4.

Frank, D.A. and McNaughton, S.J. 1993. Evidence for the promotion of aboveground grassland production by native large herbivores in Yellowstone National Park. Oecologia, 96: 157-161.

Gedan, K.B., B.R. Silliman, and M.D. Bertness. 2009. Centuries of human-driven change in salt marsh ecosystems. Annual Reviews in Marine Science. doi: 10.1146/annurev.marine.010908.163930.

Grant, K., J. Kreyling, L.F.H. Dienstbach, C. Beierkuhnlein, and A. Jentsch. 2014. Water stress due to increased intra-annual precipitation variability reduced forage yield but raised forage quality of a temperate grassland. 2014. Agriculture, Ecosystems, and Environment, 186: 1122.

He, Q. and B.R. Silliman. 2016. Consumer control as a common driver of coastal vegetation worldwide. Ecological Monographs, 86: 278-294.

Hendricks, L.G., H.E. Mossop, and C.E. Kicklighter. 2011. Palatability and chemical defense of Phragmites australis to the marsh periwinkle snail Littoraria irrorata. Journal of Chemical Ecology, 37: 838-845.

Henry, R.P., C.J. McBride, and A.H. Williams. 1993. Responses of the marsh periwinkle, Littoraria (Littorina) irrorate to temperature, salinity and dessication, and the potential 
physiological relationship to climbing behavior. Marine Behaviour and Physiology. doi: 10.1080/10236249309378877.

Herms, D.A. and W.J. Mattson. 1992. The dilemma of plants: to grow or defend. The Quarterly Review of Biology, 67: 283-335.

Hobbs, C. 2009. York River Geology. Journal of Coastal Research, 57: 10-16.

Holdredge, C., M.D. Bertness, and A.H. Altieri. 2009. Role of crab herbivory in die-off of New England salt marshes. Conservation Biology, 23: 672-679.

Infante-Izquierdo, M.D., J.M. Castillo, B.J. Grewell, F.J.J. Nieva, and A.F. Muñoz-Rodríguez. 2019. Differential effects of increasing salinity on germination of seedling growth of native and exotic invasive cordgrasses. Plants. doi: 10.3390/plants8100372.

Ito, K. and S. Sakai. 2009. Optimal defense strategy against herbivory in plants: conditions selecting for induced defense, constitutive defense, and no-defense. Journal of Theoretical Biology, 260: 453-459.

Johnson, D.S. and B.J. Jessen. 2008. Do spur-throated grasshoppers, Melanoplus spp. (Orthoptera: Acrididae), exert top-down control on smooth cordgrass Spartina alterniflora in Northern New England? Estuaries and Coasts, 31: 912-919.

Kirwan, M.L., Guntenspergen, G.R., D’Alpaos, A., Morris, J.T., Mudd, S.M., and Temmerman, S. 2010. Limits on the adaptability of coastal marshes to rising sea level. Geophyiscal Research Letters. doi: 10.1029/2010GL045489.

Kirwan, M.L. and J.P. Megonigal. 2013. Tidal wetland stability in the face of human impacts and sea-level rise. Nature. doi: 10.1038/nature12856.

Leonard, L.A. and M.E. Luther. 1995. Flow hydrodynamics in tidal marsh canopies. Limnology and Oceanography, 40: 1474-1484.

Long, J.D., J.L. Mitchell, and E.E. Sotka. 2011. Local consumers induce resistance differentially between Spartina populations in the field. Ecology, 92: 180-188.

Long, J.D. and L.D. Porturas. 2014. Herbivore impacts on marsh production depend upon a compensatory continuum mediated by salinity stress.

Luo, M., J.F. Huang, W.F. Zhu, and C. Tong. 2019. Impacts of increasing salinity and inundation on rates and pathways of organic carbon mineralization in tidal wetlands: a review. Hydrobiologia, 827: 31-49.

MacTavish, R.M. and R.A. Cohen. 2014. A simple, inexpensive, and field-relevant microcosm tidal simulator for use in marsh macrophyte studies. Applications in Plant Sciences. doi: 10.3732/apps.1400058.

MacTavish, R.M. and R.A. Cohen. 2017. Water column ammonium concentration and salinity influence nitrogen uptake and growth of Spartina alterniflora. Journal of Experimental Marine Biology and Ecology, 488: 52-59.

Massey, F.P., A.R. Ennos, and S.E. Hartley. 2007. Grasses and the resource availability hypothesis: the importance of silica-based defences. Journal of Ecology, 95: 414-424.

Mauricio, R., M.D. Rausher, and D.S. Burdick. 1997. Variation in the defense strategies of plants: are resistance and tolerance mutually exclusive? Ecology, 78: 1301-1311.

Montagna, P., Palmer, P., and Pollack, J. 2013. Hydrological Changes and Estuarine Dynamics. Springerbriefs in Environmental Science Volume 8. 94 pp. DOI: DOI 10.1007/978-1-46145833-3.

Morris, J.T., P.V. Sundareshwar, C.T. Nietch, B. Kjerfve, and D.R. Cahoon. 2002. Responses of coastal wetlands to rising sea level. Ecology, 83: 2869-2877. 
Munns, R. 2002. Comparative physiology of salt and water stress. Plant, Cell and Environment, 25: 239-250.

Najjar, R.G., C.R. Pyke, M.B. Adams, D. Breitburg, C. Hershner, M. Kemp, R. Howarth, M.R. Mulholland, M. Paolisso, D. Secor, K. Sellner, D. Wardrop, R. Wood. 2010. Potential climate-change impacts on the Chesapeake Bay. Estuarine, Coastal and Shelf Science, 86: 120.

Neilson, E.H., J. Q.D. Goodger, I.E. Woodrow, and B.L. Møller. 2013. Plant chemical defense: at what cost? Trends in Plant Science, 18: 250-258.

Odum, W.E. 1988. Comparative ecology of tidal freshwater and salt marshes. Annual Review of Ecology and Systematics, 19: 147-176.

Pennings, S.C., T.H. Carefoot, E.L. Siska, M.E. Chase, and T.A. Page. 1998. Feeding preferences of a generalist salt-marsh crab: relative importance of multiple plant traits. Ecology, 79: 1968-1979.

Perry, J.E. and Atkinson, R.B. 1997. Plant diversity along a salinity gradient of four marshes on the York and Pamunkey Rivers in Virginia. Castanea, 62: 112-118.

R: A language and environment for statistical computing. R Foundation for Statistical Computing, Vienna, Austria. http://www.r-project.org/index.html

Rhoads, D.F. 1979. Evolution of plant chemical defense against herbivores. In Herbivores: their interaction with secondary plant metabolites, eds. G.A. Rosenthal and D.H., 3-54. Academic Press.

Salgado, C.S. and S.C. Pennings. 2005. Latitudinal variation in palatability of salt-marsh plants: are differences constitutive? Ecology, 86: 1571-1579.

Sallenger Jr., A.H., K.S. Doran, and P.A. Howd. 2012. Hotspot of accelerated sea-level rise on the Atlantic coast of North America. Nature Climate Change. doi: 10.1038/NCLIMATE1597.

Sieg, R.D., K. Wolfe, D. Willey, V. Ortiz-Santiago, and J. Kubanek. 2013. Chemical defenses against herbivores and fungi limit establishment of fungal farms on salt marsh angiosperms. Journal of Experimental Marine Biology and Ecology, 446: 122-130.

Silliman, B.R., J. van de Koppel, M.D. Bertness, L.E. Stanton, and I.A. Mendelssohn. 2005. Drought, snails, and large-scale die-off of southern U.S. salt marshes. Science, 310: 18031806.

Siska, E.L., S.C. Pennings, T.L. Buck, and M.D. Hanesak. 2002. Latitudinal variation in palatability of salt-marsh plants: which traits are responsible? Ecology, 83: 3369-3381.

Stamp, N. 2003. Out of the quagmire of plant defense hypotheses. The Quarterly Review of Biology, 78: 23-55.

Staton, J.L. and Felder, D.L. 1992. Osmoregulatory capacities in disjunct western Atlantic populations of the Sesarma reticulatum complex (Decapoda: Grapsidae). Journal of Crustacean Biology, 12: 335-341.

Stowe, K.A., R.J. Marquis, C.G. Hochwender, and E.L. Simms. 2000. The evolutionary ecology of tolerance to consumer damage. Annual Review of Ecology and Systematics, 31: 565-595.

Strauss, S.Y. and A.A. Agrawal. 1999. The ecology and evolution of plant tolerance to herbivory. TREE, 14: 179-185.

Sutter, L.A., R.M. Chambers, and J.E. Perry III. 2015. Seawater intrusion mediates species transition in low salinity, tidal marsh vegetation. Aquatic Botany, 122: 32-39. 
Sutter, L.A., R.M. Chambers, M. Karp, and J.E. Perry III. 2019. A test of top-down control on plant production and nutrient quality in low-salinity tidal marshes. Aquatic Sciences, 81: 1516.

Tiffin, P. 2000. Mechanisms of tolerance to herbivore damage: what do we know? Evolutionary Ecology, 14: 523-536.

VECOS Database. Virginia Estuarine and Coastal Observing System. Stations: PMK012.18 (Sweet Hall Marsh) and TSK000.23 (Taskinas Creek). http://vecos.vims.edu/. Accessed March 15, 2020.

Vu, H.D., K. Więski, and S.C. Pennings. 2017. Ecosystem engineers drive creek formation in salt marshes. Ecology, 98: 162-174.

Więski, K. and S. Pennings. 2014. Latitudinal variation in resistance and tolerance to herbivory of a salt marsh shrub. Ecography, 37: 763-769.

Wittyngham, S.S., J. Moderan, and K.E. Boyer. 2019. Temperature and salinity effects on submerged aquatic vegetation traits and susceptibility to grazing. Aquatic Botany. doi: 10.1016/j.aquabot.2019.05.004.

Zhang, P., B.M.C. Grutters, C.H.A. van Leeuwen, J. Xu, A. Petruzzella, R.F. van den Berg, and E.S. Bakker. 2019. Effects of rising temperature on the growth, stoichiometry, and palatability of aquatic plants. Frontiers in Plant Science. doi: 10.3389/fpls.2018.01947. 
547 Table 1. Model selection for each response variable. Bolded model indicates best fit based on

548 AICc and weight. Explanatory variables with an asterisk (*) indicate significance. Response

549 variables with two asterisks $(* *)$ were log transformed to meet assumptions and those with three

550 asterisks $(* * *)$ were transformed with Box-Cox. (Abbreviations for explanatory variables: Sa =

551 Salinity, $\mathrm{Cl}=$ Clipping, $\mathrm{Si}=$ Site, $\mathrm{IAB}=$ Initial Aboveground Biomass, $\mathrm{NSB}=$ New Stem

552 Biomass, $\mathrm{N}=$ Nitrogen).

\begin{tabular}{|c|c|c|c|c|}
\hline Response Variable & Explanatory Variables & $\mathbf{k}$ & AICc & Weight \\
\hline \multirow[t]{4}{*}{ Carbon } & $\mathrm{Sa}+\mathrm{Cl}$ & 4 & 258.5234 & $<0.01$ \\
\hline & $\mathrm{Sa}+\mathrm{Cl}+\mathrm{Si}$ & 5 & 253.1361 & $<0.01$ \\
\hline & $\mathrm{Sa}+\mathrm{Cl}+\mathrm{Si}+\mathrm{IAB}$ & 6 & 254.4296 & $<0.01$ \\
\hline & $\mathrm{Sa}^{*}+\mathbf{C l}+\mathrm{Si}^{*}+\mathbf{I A B}+\mathbf{N S B}$ & 7 & 241.2353 & 0.99 \\
\hline \multirow[t]{4}{*}{ Nitrogen $* *$} & $\mathrm{Sa}^{*}+\mathrm{CI}^{*}$ & 4 & 4.425692 & 0.58 \\
\hline & $\mathrm{Sa}+\mathrm{Cl}+\mathrm{Si}$ & 5 & 5.802641 & 0.29 \\
\hline & $\mathrm{Sa}+\mathrm{Cl}+\mathrm{Si}+\mathrm{IAB}$ & 6 & 7.976806 & $<0.01$ \\
\hline & $\mathrm{Sa}+\mathrm{Cl}+\mathrm{Si}+\mathrm{IAB}+\mathrm{NSB}$ & 7 & 10.140312 & $<0.01$ \\
\hline \multirow[t]{4}{*}{$\mathrm{C}: \mathrm{N}$} & $\mathrm{Sa}+\mathrm{Cl}$ & 4 & 466.4417 & $<0.01$ \\
\hline & $\mathrm{Sa}+\mathrm{Cl}+\mathrm{Si}$ & 5 & 466.2139 & $<0.01$ \\
\hline & $\mathrm{Sa}+\mathrm{Cl}+\mathrm{Si}+\mathrm{IAB}$ & 6 & 468.6781 & $<0.01$ \\
\hline & $\mathrm{Sa}^{*}+\mathrm{Cl}^{*}+\mathrm{Si}^{*}+\mathrm{IAB}+\mathrm{NSB}$ & 7 & 438.3512 & 0.99 \\
\hline \multirow[t]{7}{*}{ Protein** } & $\mathrm{Sa}+\mathrm{Cl}$ & 4 & -35.84847 & $<0.01$ \\
\hline & $\mathrm{Sa}+\mathrm{Cl}+\mathrm{Si}$ & 5 & -33.72827 & $<0.01$ \\
\hline & $\mathbf{C l}+\mathbf{N}^{*}$ & 4 & -42.04862 & 0.48 \\
\hline & $\mathrm{Sa}+\mathrm{Cl}+\mathrm{N}$ & 5 & -40.08086 & 0.18 \\
\hline & $\mathrm{Cl}+\mathrm{N}+\mathrm{NSB}$ & 5 & -40.90411 & 0.27 \\
\hline & $\mathrm{Sa}+\mathrm{Cl}+\mathrm{Si}+\mathrm{IAB}+\mathrm{N}$ & 7 & -36.32555 & $<0.01$ \\
\hline & $\mathrm{Sa}+\mathrm{Cl}+\mathrm{Si}+\mathrm{IAB}+\mathrm{N}+\mathrm{NSB}$ & 8 & -34.43539 & $<0.01$ \\
\hline \multirow[t]{2}{*}{ Phenolics** } & $\mathrm{Sa}+\mathrm{Cl}$ & 4 & 43.01449 & $<0.01$ \\
\hline & $\mathrm{Sa}+\mathrm{Cl}+\mathrm{Si}$ & 5 & 45.16761 & $<0.01$ \\
\hline
\end{tabular}




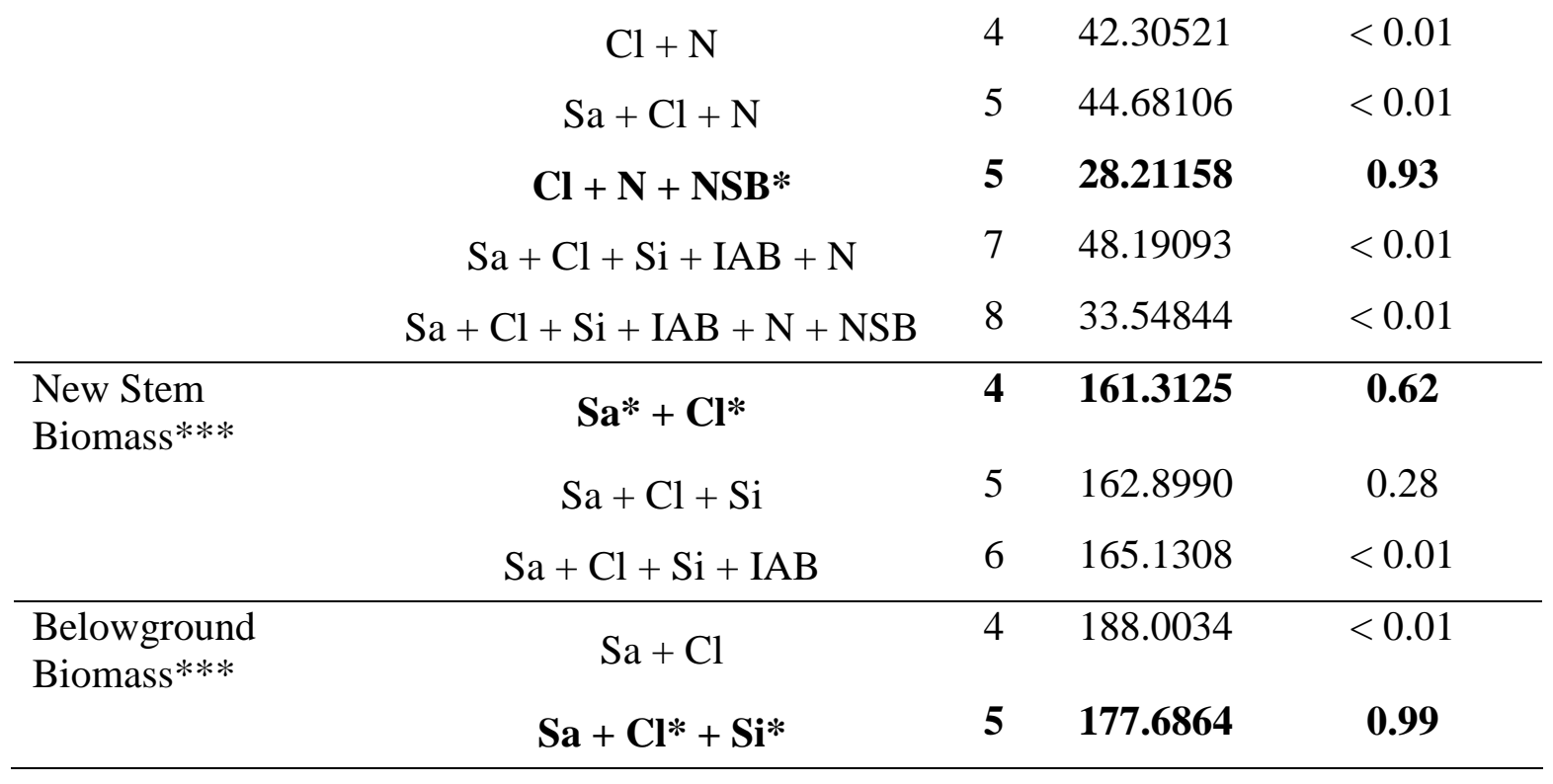

553

554

555

556

557

558

559

560

561

562

563

564

565

566

567

568

569

570

571

572

573

574

575

576

577

578

579

580

581

582 


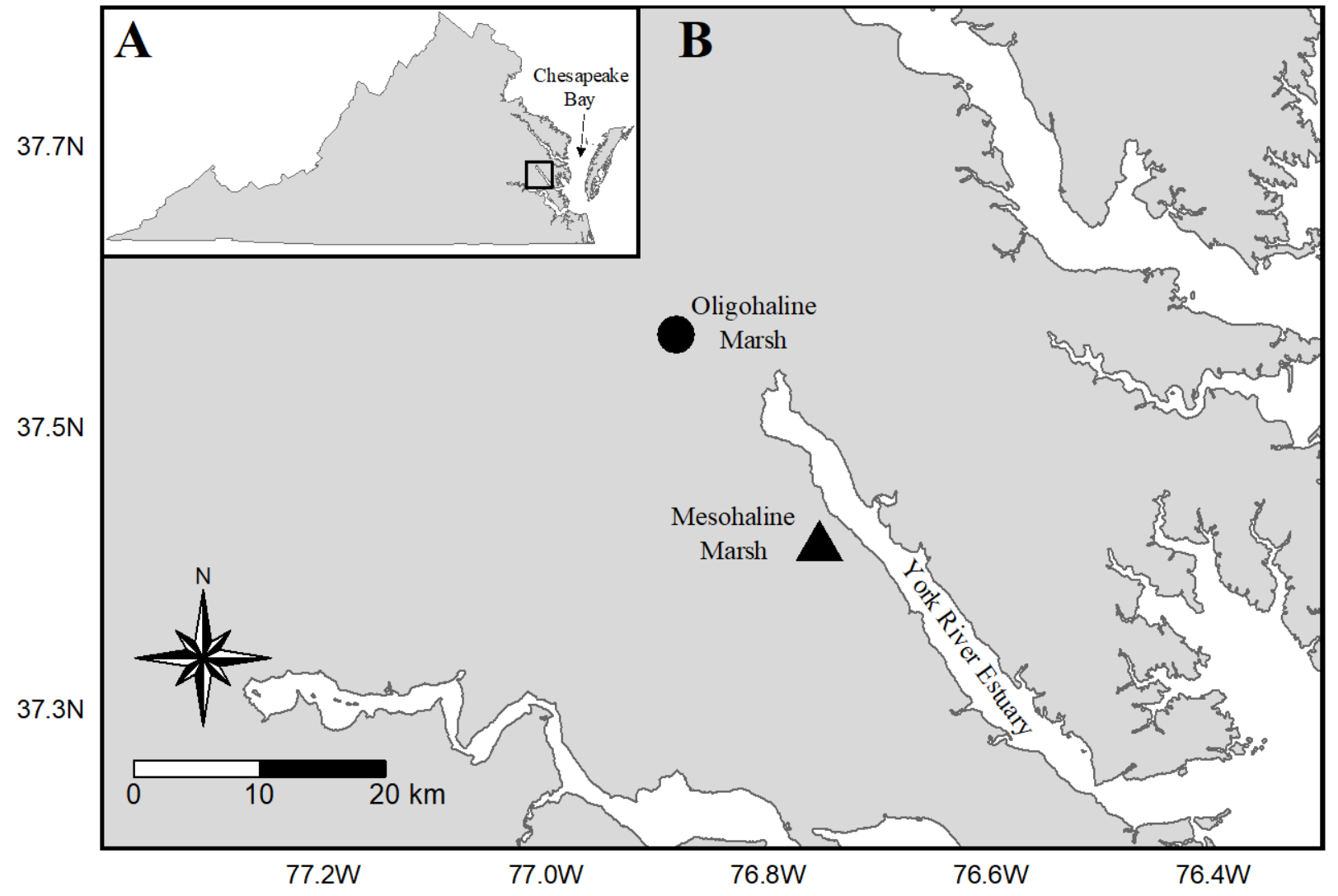

Fig. 1 A) Inset map of the state of Virginia, U.S.A. Boxed area indicates study region. B) Enlarged map of study region along the York River Estuary. The circle represents the oligohaline marsh (Sweet Hall) and the triangle the mesohaline marsh (Taskinas Creek) 

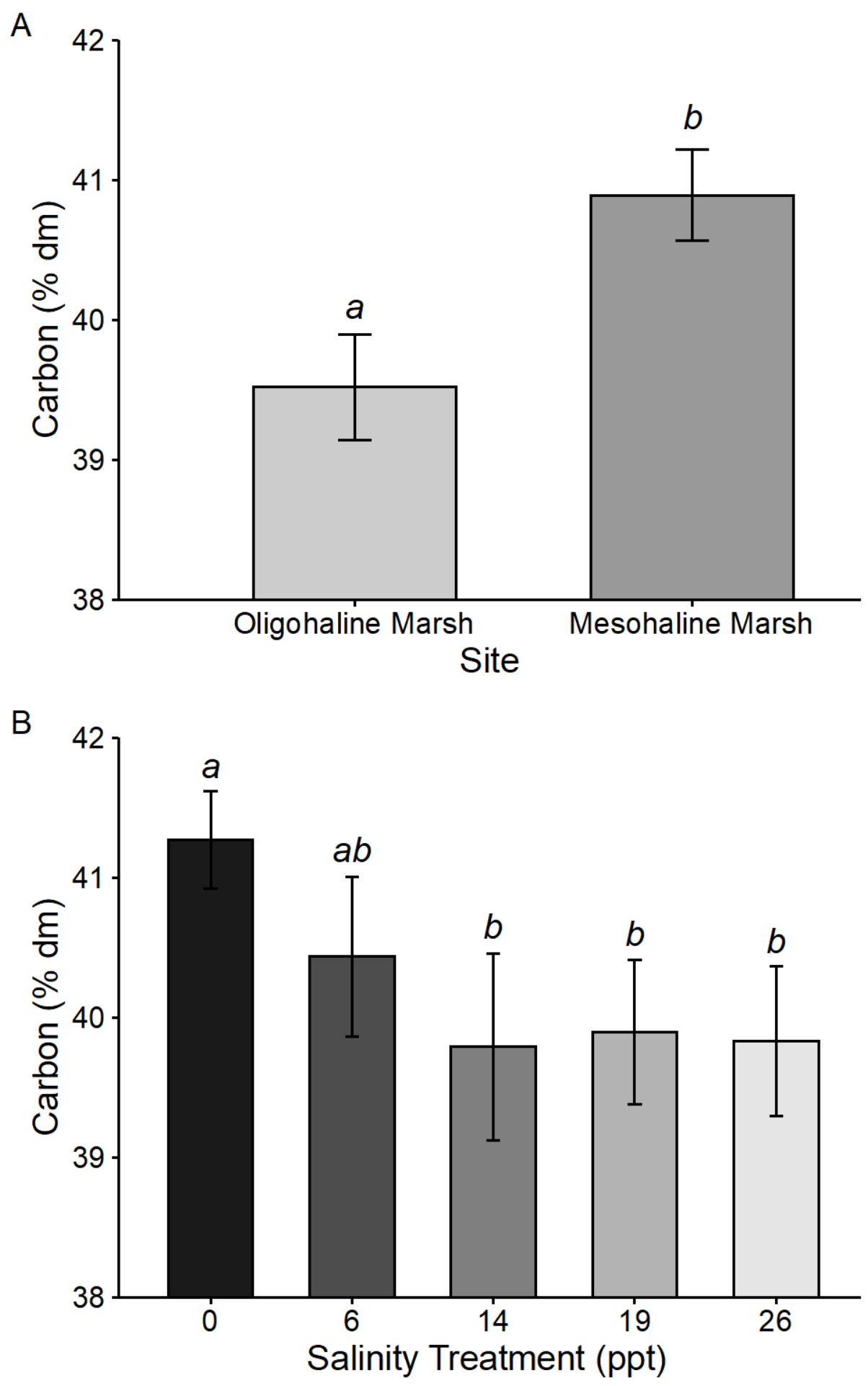

Fig. 2 Mean carbon content (percent dry mass) of S. alterniflora tissues A) by collection site 592 (oligohaline or mesohaline marsh) and B) subjected to one of five salinity treatments (0, 6, 14, 59319 , or $26 \mathrm{ppt}$ ). Italicized letters above bars indicate significance between treatments. Error bars 594 represent standard error 

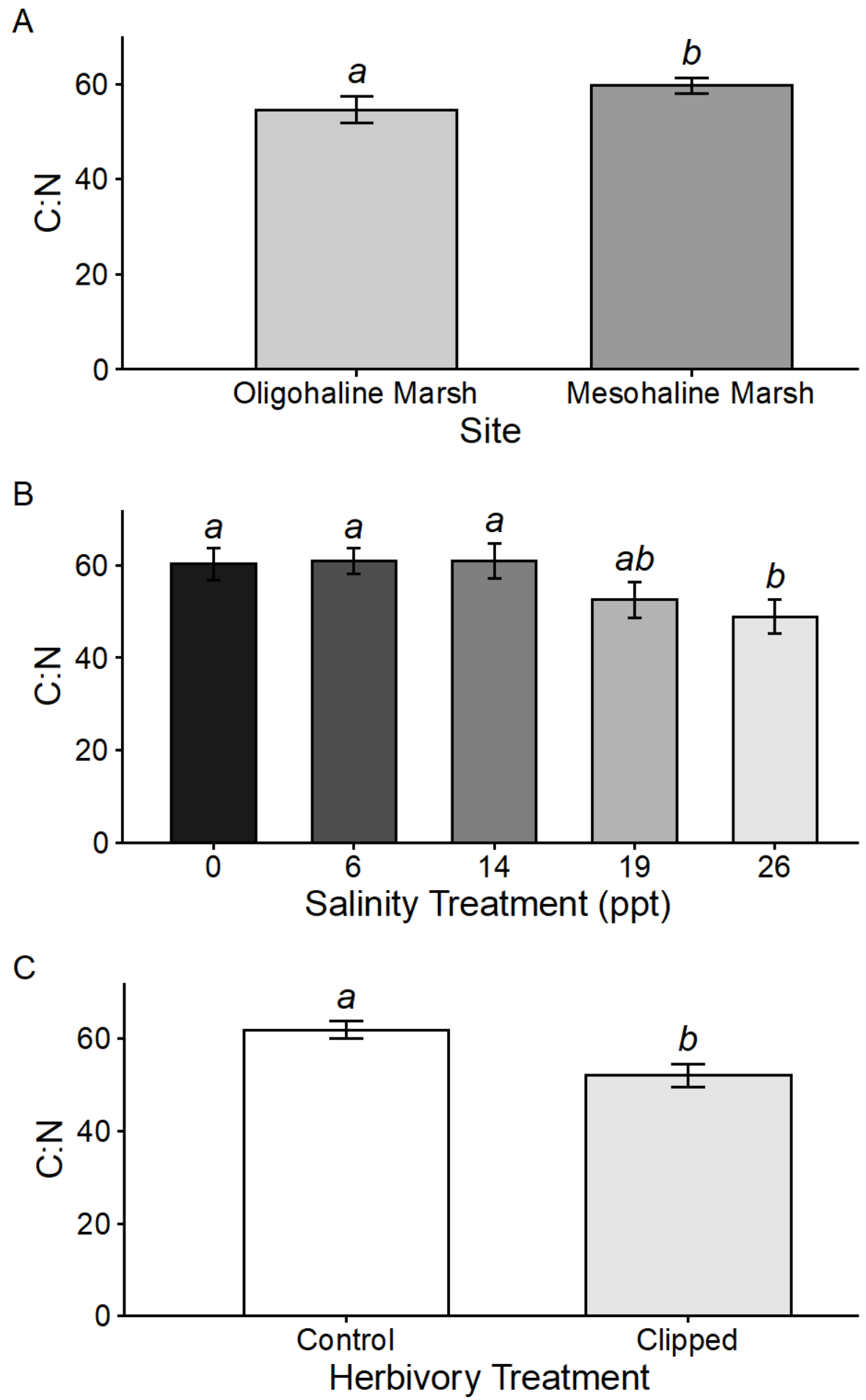

Fig. 3 Mean C:N molar ratios of S. alterniflora tissues A) by collection site (oligohaline or mesohaline marsh), B) subjected to one of five salinity treatments $(0,6,14,19$, or $26 \mathrm{ppt})$, and C) by simulated herbivory treatment (control or clipped). Italicized letters above bars indicate significance between treatments. Error bars represent standard error 

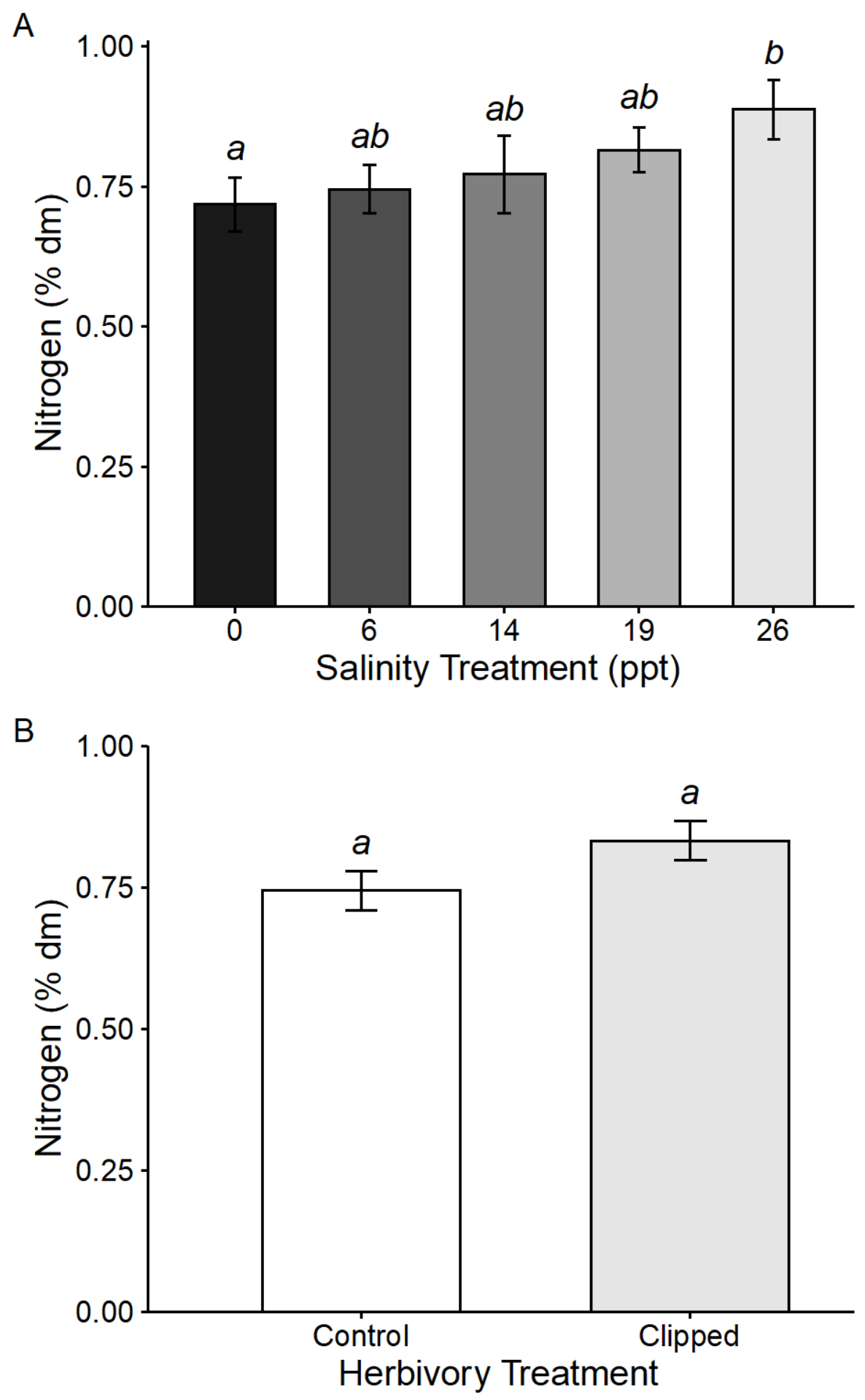

Fig. 4 Mean nitrogen content (percent dry mass) of S. alterniflora tissues A) subjected to one of five salinity treatments $(0,6,14,19$, or $26 \mathrm{ppt})$ and B) by simulated herbivory treatment (control or clipped). Italicized letters above bars indicate significance between treatments. Error bars 608 represent standard error 

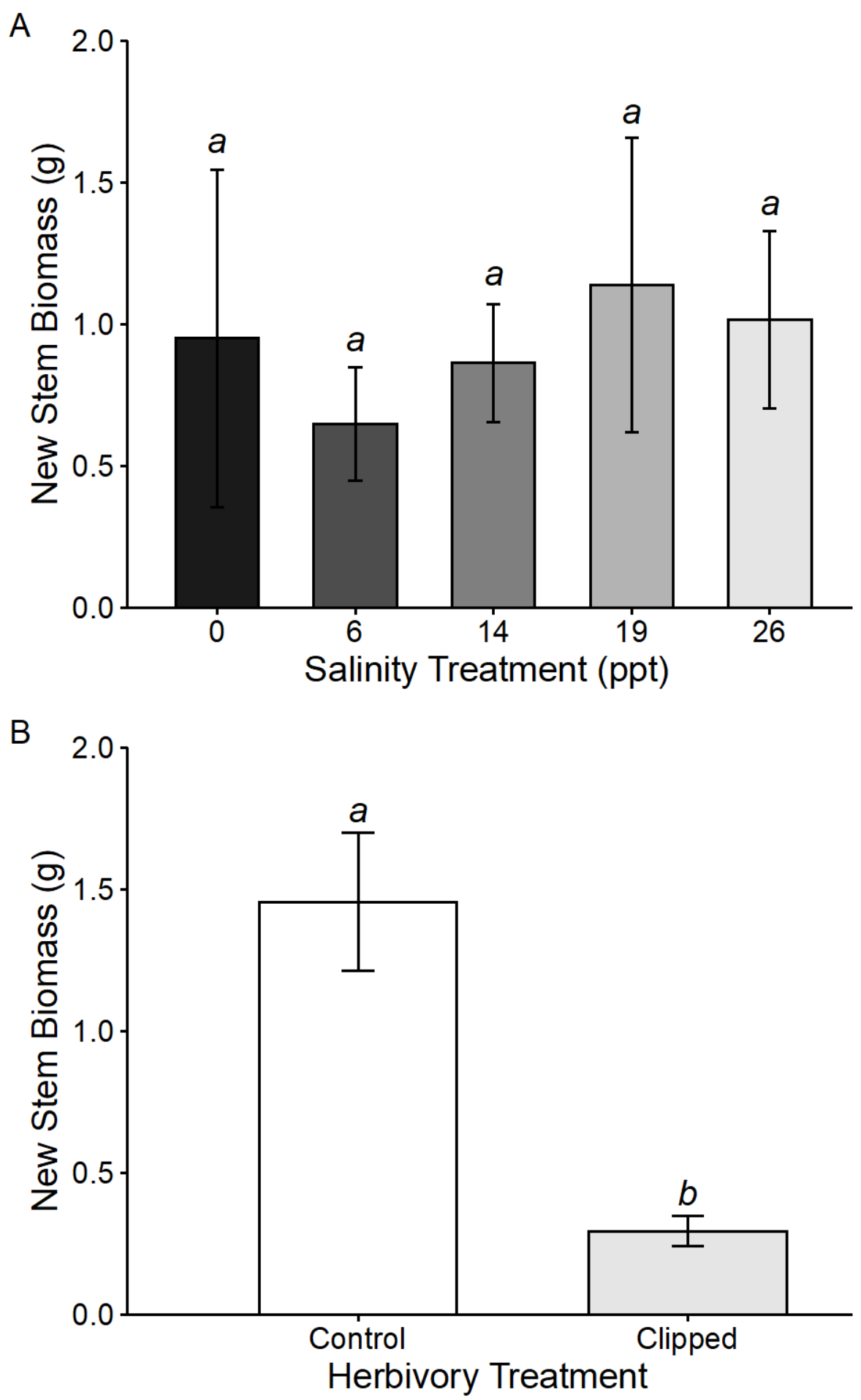

Fig. 5 Mean dry biomass (grams) of new stems produced by S. alterniflora A) subjected to one of five salinity treatments $(0,6,14,19$, or $26 \mathrm{ppt})$ and B) by simulated herbivory treatment (control or clipped). Italicized letters above bars indicate significance between treatments. Error bars represent standard error 

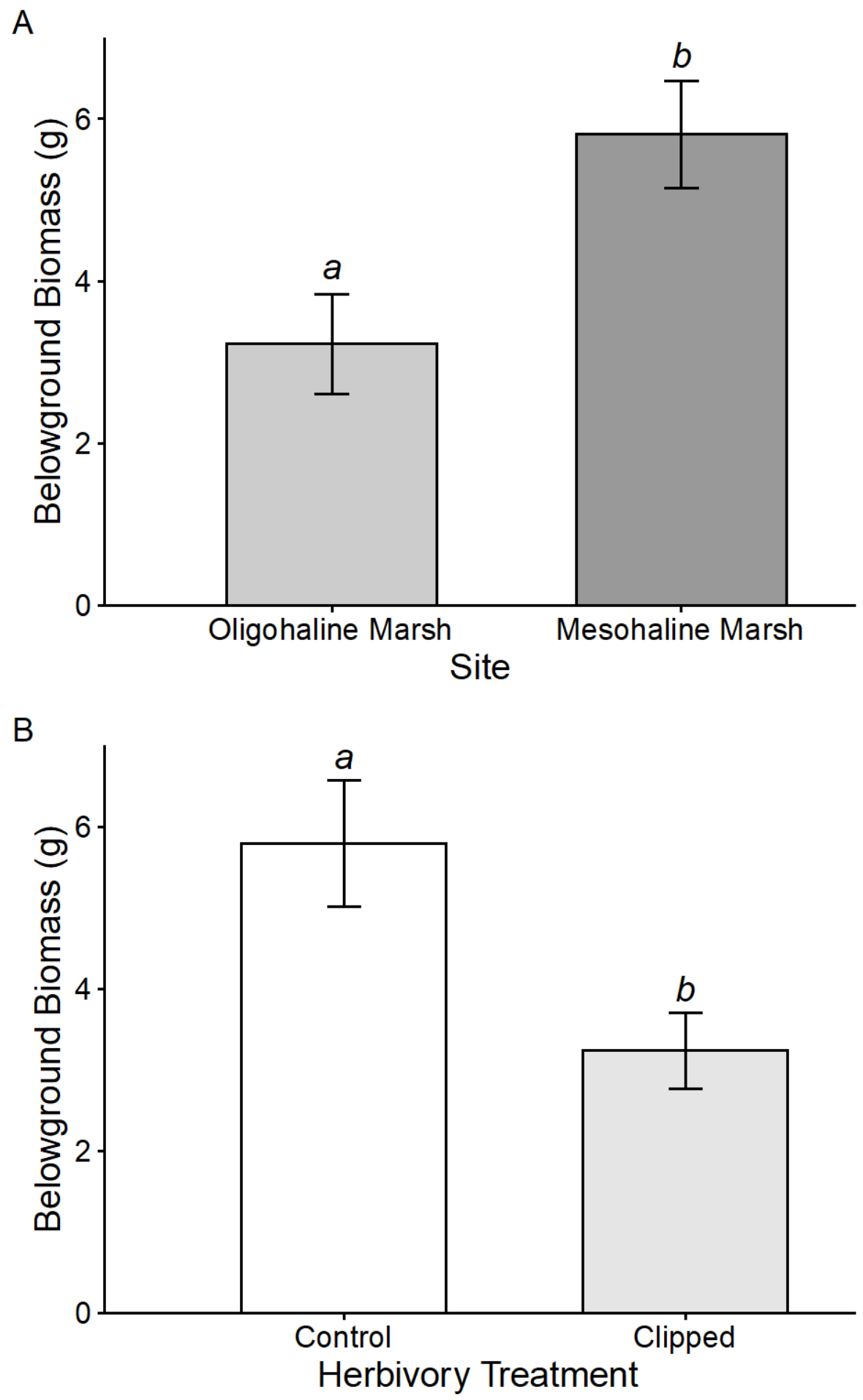

Fig. 6 Mean dry belowground biomass (grams) of S. alterniflora A) by collection site

620 (oligohaline or mesohaline marsh) and B) by simulated herbivory treatment (control or clipped).

621 Italicized letters above bars indicate significance between treatments. Error bars represent

622 standard error 
625

626

\section{Electronic Supplementary Material}

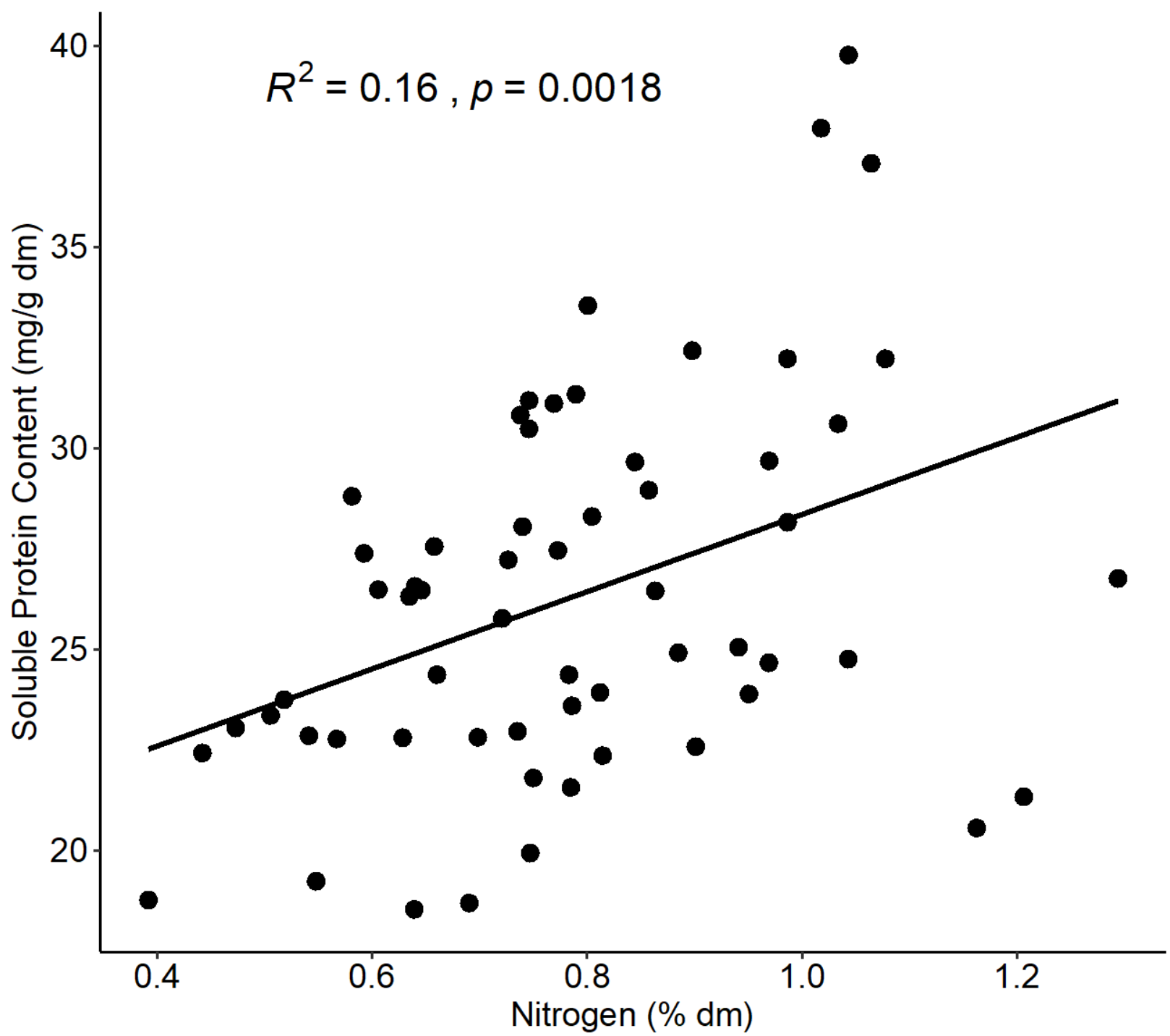

627

628

629

630

631
ESM 1 Mean soluble protein content (milligrams/gram dry mass) of S. alterniflora tissues across nitrogen content (percent dry mass). Trend line represents smoothed linear regression line 


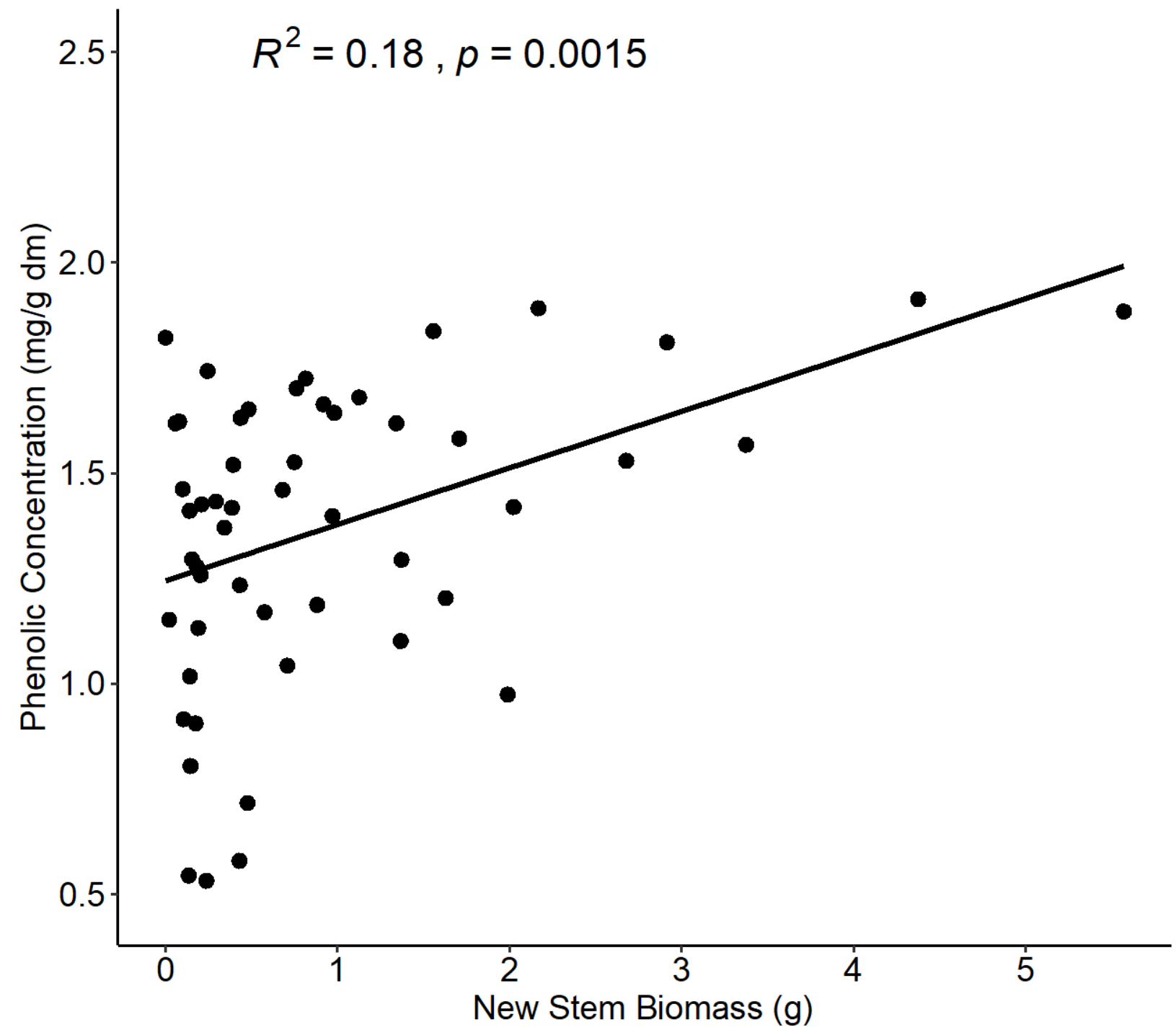

ESM 2 Mean phenolic concentrations (milligrams/gram dry mass) of S. alterniflora tissues across new stem biomass (grams). Trend line represents smoothed linear regression line 